\title{
Modeling of runoff formation processes in mountain conditions of the Crimean Peninsula (Russia)
}

\author{
Anastasiia Zemlyanskova $^{1 *}$, Olga Makarieva $^{1,2}$, Nataliia Nesterova $^{1,3}$, and Alexandra Fedorova ${ }^{1}$ \\ ${ }^{1}$ Saint-Petersburg State University, 199034 Saint-Petersburg, Russia \\ ${ }^{2}$ Melnikov Permafrost Institute, 677010 Yakutsk, Russia \\ ${ }^{3}$ State Hydrological Institute, 199053 Saint-Petersburg, Russia
}

\begin{abstract}
The distributed hydrological model Hydrograph was applied to simulate runoff formation processes in the mountainous conditions of the Crimean Peninsula. The study object is the Derekoyka River watershed $\left(49.7 \mathrm{~km}^{2}\right.$, the altitude difference $\left.14-1398 \mathrm{~m}\right)$. Streamflow simulations were carried out with daily time step for the periods of 1967-1988 and 2016-2017 using the data of two weather stations Ai-Petri and Yalta. Though mean and median Nash-Sutcliffe efficiency was only 0.28 and 0.33 , in some years it exceeded 0.60 . The analysis has shown that the precipitation input interpolated from weather stations was not always adequate affecting the quality of streamflow simulations. The results of the model verification were accepted as satisfactory. The hazardous flood of 2018 in Yalta was simulated. According to simulations, maximum daily discharge amounted to $14.9 \mathrm{~m}^{3} / \mathrm{s}$ and exceeded previous maximum value observed in 1962. The results confirm the possibility to apply the model Hydrograph to assess the water balance and hydrological characteristics in the mountainous part of the Crimean Peninsula. We suggest that provided by proper precipitation data the model can be used for short-term forecasts of hazardous floods in the region.
\end{abstract}

\section{Introduction}

The Crimean Peninsula is one of the scarcest areas of Russia in terms of water resources. In addition, the territory is characterized by extremely uneven distribution of runoff. The functioning of the North Crimean Canal, which supplied water to the Peninsula, was terminated for political reasons on April 26, 2014, which led to a number of problems: lack of water supply for the population, agriculture and industry, the threat of ecocide. To address the issue, Russian Federation Ministry of Natural Resources initiated the plan for the period 2014-2020 which set the priority measures to provide uninterrupted supplies of water to industry and population [10]. One of the main aspects of the plan is the rational use and planning of local water resources, including in the conditions of climate change.

In $[3,13]$ the analysis of climate variables changes in the Crimea, including its mountainous part, for the modern period were presented. The studies have shown that the

\footnotetext{
* Corresponding author: anastasiazemlanskova@gmail.com
} 
increase of air temperature and the change of precipitation occur unevenly throughout the year and therefore may have nonlinear impact on hydrological regime [3].

Most of touristic resorts are situated at the coast of mountainous Crimea. Intense local precipitation in mountainous relief causes dangerous floods which may lead to significant economic damage [12]. Active development of the territory requires the estimates of hydrological characteristics. Available hydrological information for historical period is lacking quite a long period of 1990-2015. Moreover, at the moment there are only 32 hydrological gauges on the Crimean Peninsula which provide the data on streamflow discharges. Modelling approach could be used to substitute the lacking hydrological data.

The aim of the study is to parameterize hydrological model Hydrograph [16] to the conditions of the mountainous part of the Crimea, simulate runoff formation processes for the continuous period, verify the model and evaluate the magnitude of the hazardous flood of 2018 in one of the resort towns of the Crimea.

\section{Study area}

The object of the study is the watershed of the Derekoyka River - Yalta (area $49.7 \mathrm{~km}^{2}$ ). The hydrological gauge is located at the southern coast of the Crimea at the altitude $14 \mathrm{~m}$, while the highest altitude of slopes reaches $1398 \mathrm{~m}$ (Fig. 1).

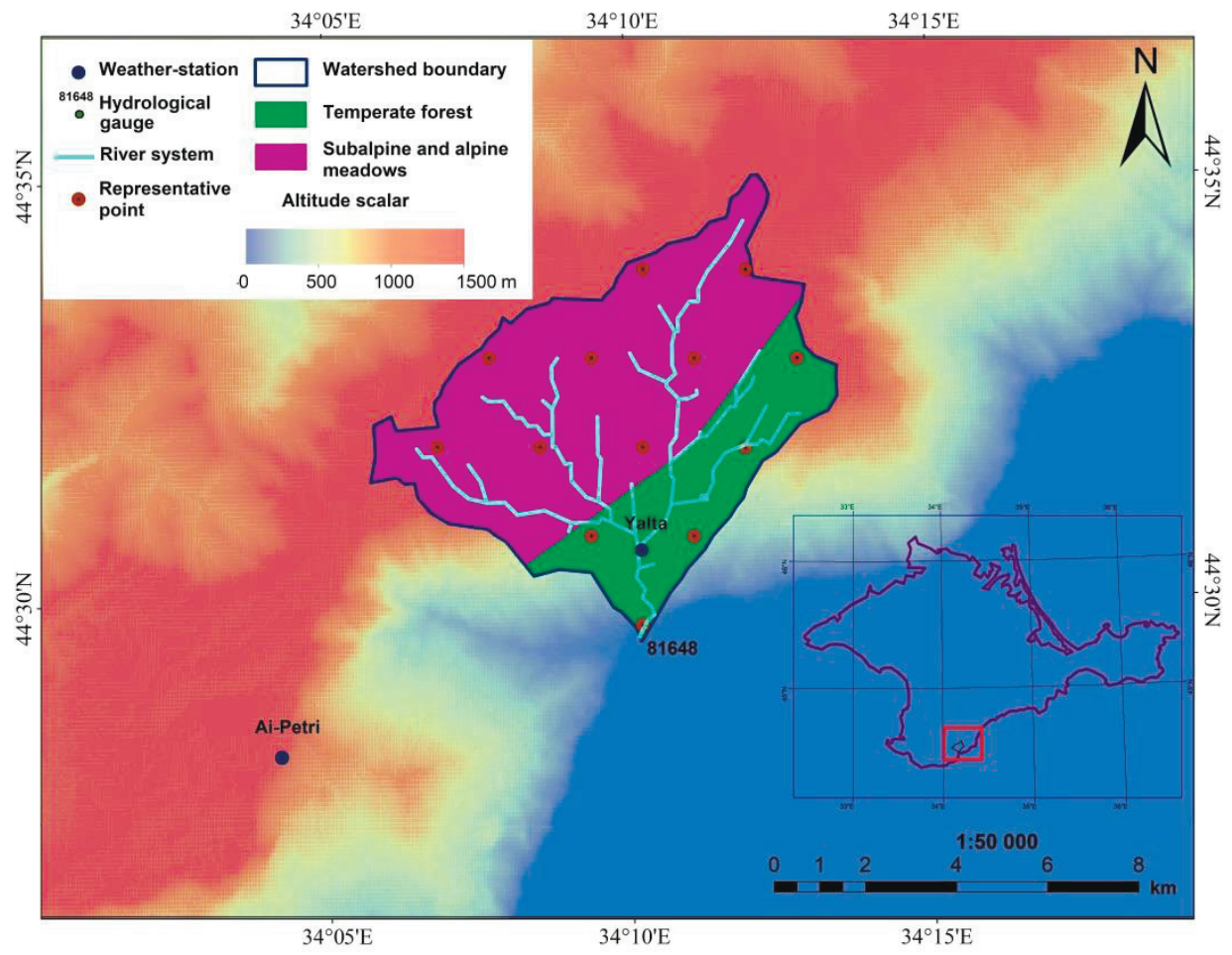

Fig. 1. The scheme of the Derekoyka River watershed.

The climate of the study area is the Mediterranean; however it depends on the altitude. The average annual air temperature and precipitation are $13.0^{\circ} \mathrm{C}$ and $620 \mathrm{~mm}$ at Yalta station $(72 \mathrm{~m}), 5.9^{\circ} \mathrm{C}$ and $1050 \mathrm{~mm}$ at Ai-Petry station $(1180 \mathrm{~m})$. The maximum daily precipitation was recorded in December, there are $100 \mathrm{~mm}$ in Yalta in 1999 [9] and 215 $\mathrm{mm}$ in Ai-Petri in 1962 [1]. 
Due to high altitude snow cover is formed in the upper parts of the watershed. In average the snow cover period lasts from December to beginning of May, snow water equivalent averaged by basin area may reach up to $240 \mathrm{~mm}$, but mean annual value amounts to $90 \mathrm{~mm}$.

The landscapes of the studied territory are represented by temperate forest and subalpine and alpine meadows at the mountain area. The study area is characterized by widespread distribution of karst.

The Derekoyka River belongs to the mountain-forest zone of a warm climate, where floods are typical for entire year [12]. The observations of streamflow on this river have been carried out since 1913, daily streamflow hydrographs are available for the period 1946-1988 and 2016-2017. During this period, the average daily discharge was $0.7 \mathrm{~m}^{3} / \mathrm{s}$, maximum daily discharge reaching $13.1 \mathrm{~m}^{3} / \mathrm{s}$ was observed on the $17^{\text {th }}$ of December 1962 .

\section{Methods}

Distributed hydrological model Hydrograph is used in this study [17]. The algorithms of the model combine physically-based and conceptual approaches in describing runoff formation processes. The Hydrograph model was successfully applied in conditions of small, medium and large basins of the Russian Federation, including the mountainous rivers of the Black Sea coast of the Krasnodar region which basins have similar to the Crimea climate and landscape characteristics $[5,7]$.

To parameterize the Hydrograph model, the landscapes that are relatively homogeneous in hydrogeological, hydrographic, and hypsometric characteristics and where runoff formation process is qualitatively uniform, were identified within the watershed area. These landscapes are called runoff formation complexes (RFC). Each RFC has its own set of soil and vegetation parameters. The Derekoyka river watershed was divided into two RFC: subalpine and alpine meadows and temperate forest (Fig. 1) [4]. The successful use of the Hydrograph model was demonstrated for similar landscapes of the Black Sea coast of the Krasnodar region [5, 7], therefore the parameters of the model for the Derekoyka watershed were adopted from these studies. As calculation grid points, a regular hexagonal grid of representative points (RP) is used (Fig. 1). For each of 14 assigned RP, the following characteristics were determined: latitude, altitude, inclination and slope aspect, lag time from an RP to a gauging section by river network, as well as the type of runoff formation complexes (RFC). A more detailed description of the model and methods of its parameterization can be found in [14-16].

\section{Results of model verification}

The simulation of daily streamflow was carried out for two periods with available meteorological data: 1967-1988 and 2016-2017. The daily data of air temperature, air moisture deficit and precipitation from two weather stations, which are located in the closest vicinity to the watershed, are used as the model input to simulate the streamflow of the Derekoyka River (Fig. 1). To interpolate the data into RP the elevation gradients of meteorological variables are introduced: $-0.6^{\circ} \mathrm{C}$ and $40 \mathrm{~mm}$ per $100 \mathrm{~m}$ of altitude.

For the modelling period, the simulated values of annual water balance elements were distributed as the following: precipitation $-840 \mathrm{~mm}$, evaporation $-490 \mathrm{~mm}$, runoff -340 $\mathrm{mm}$. The observed runoff amounted to $370 \mathrm{~mm}$, therefore the difference between observed and calculated runoff is $30 \mathrm{~mm}$, or $8 \%$. The Nash-Sutcliffe efficiency criterion (NS) was used as a mathematical measure of simulation errors [8]. Mean and median values of NS amounted to 0.28 and 0.33 for calculation period. Maximum NS values reached 0.75 in 
1980, the minimum was -0.76 in 1977 . The comparison of simulated and observed streamflow hydrographs (Fig. 2) indicates that the quality of simulated streamflow crucially depends on the precipitation input. The rainfall in mountainous areas is very local, in the Crimea as well [12]. Makarieva et al. (2018) [7] have shown that the efficiency of streamflow simulations increases significantly if at least one weather station is situated within the small mountainous basin.

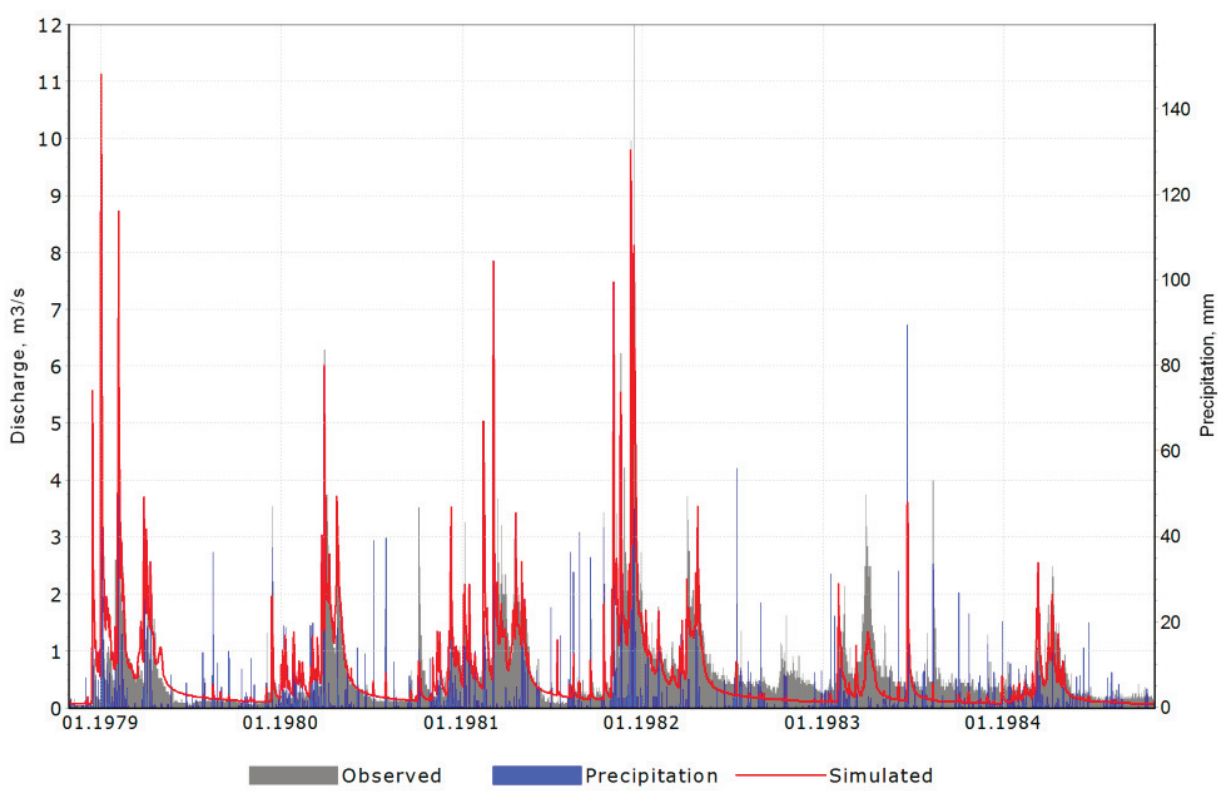

Fig. 2. Observed and simulated streamflow hydrographs $\left(\mathrm{m}^{3} / \mathrm{s}\right)$ and daily precipitation $(\mathrm{mm}), 1979$ 1984.

In the situation when it is objectively that precipitation from weather stations may be not representative for a watershed, it is reasonable to compare not the specific hydrographs but the curves of exceedance probabilities of different hydrological characteristics. In this study we followed the approach presented in [6] and compared the probabilistic curves of simulated and observed maximum discharges (Fig. 3). In general observed and simulated curves coincide satisfactorily. Mostly simulated discharges exceed observed ones, but not more than by $40 \%$. We conclude that the quality of simulations can be assessed as the satisfactory and given proper forecast of precipitation the model would be able to reproduce streamflow in the studied watershed.

\section{Assessment of hazardous flood in Yalta town, 2018}

In 2018, after prolonged hot and dry weather, on the $6^{\text {th }}$ of September heavy downpours occurred. They were caused by sedentary cyclone formed over the Black sea and the southern territory of the Crimean Peninsula. Thundershowers brought $71 \mathrm{~mm}$ and $83 \mathrm{~mm}$ at and Yalta stations in one day [11]. In Yalta region, the mudflows were formed; they brought soil and stones to the roadways of the region, many buildings in Yalta were flooded [2]. The data on maximum discharge of this flood is not available.

We used NOAA climate data [9] to simulate the flood of 2018. The data from weather station Ai-Petry was available. The data from Yalta station was restored based on the dependencies of meteorological valuables between two stations. The published value of daily precipitation of $83 \mathrm{~mm}$ [11] was assigned to Yalta station. According to modelling 
results the value of maximum daily discharge on the $6^{\text {th }}$ September of 2018 reached 14.9 $\mathrm{m}^{3} / \mathrm{s}$ which exceeded previously observed flood in $1962\left(13.1 \mathrm{~m}^{3} / \mathrm{s}\right)$ by $1.8 \mathrm{~m}^{3} / \mathrm{s}$ (about $14 \%)$.

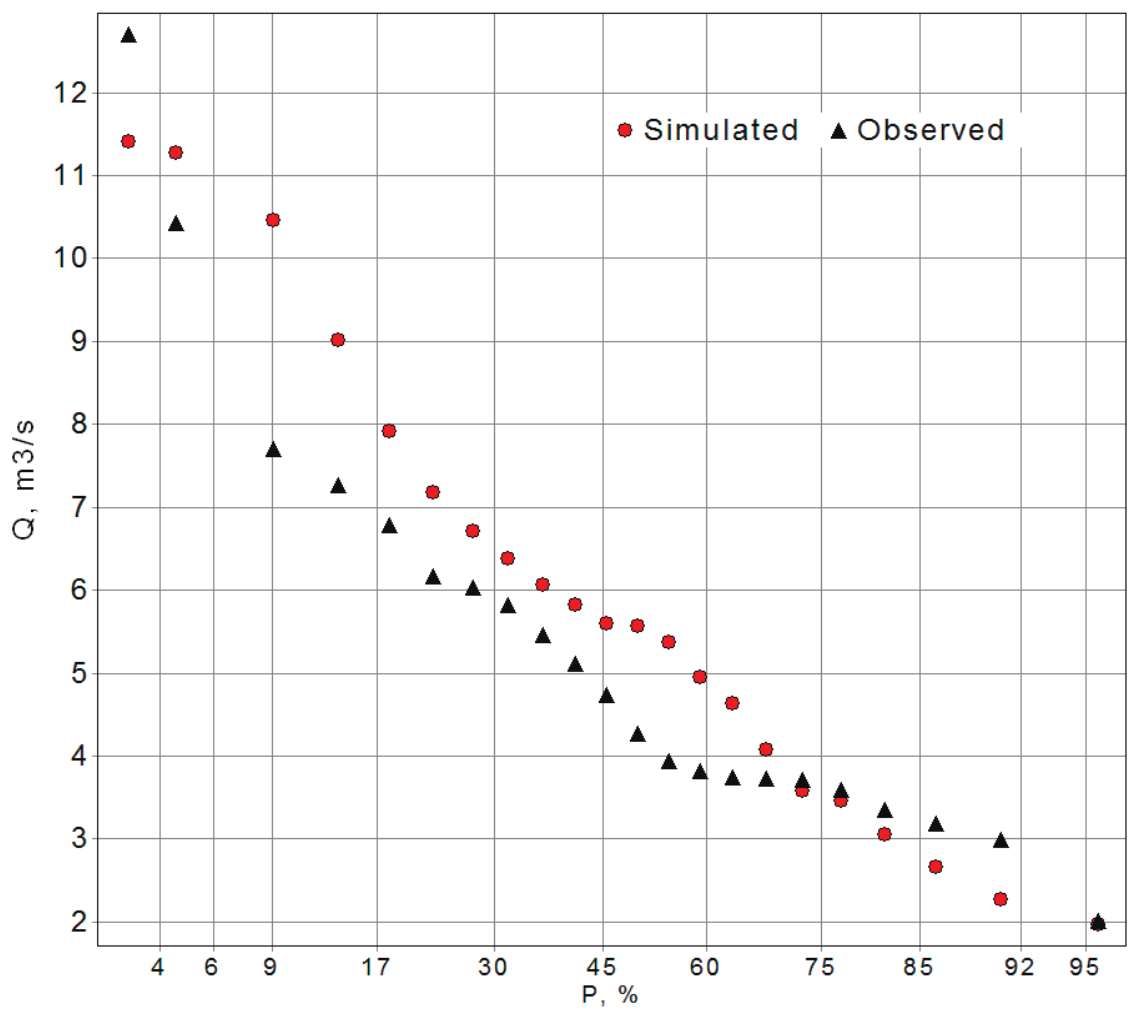

Fig. 3. Exceedance probabilities curves of maximum daily water discharge.

Precipitation averaged by the area of the watershed reached $110 \mathrm{~mm}$ on the $6^{\text {th }}$ of September and $65 \mathrm{~mm}$ on the $7^{\text {th }}$ of September, corresponding daily flow depth amounted to 25 and $18 \mathrm{~mm}$ at the same dates. According to our calculations the flood of 2018 bit the historical record. It should be noted that we simulated daily discharge and the instant value is supposed to be much higher.

\section{Conclusions}

To assess the possibility of using a hydrological model to calculate water flow rates for the mountainous rivers of the Crimean Peninsula by the example of the Derekoyka River the following tasks were implemented:

1. Schematization of the Derekoyka River catchment was performed, two runoff formation complexes were identified, and the parameters of the hydrological model were estimated.

2. Modeling of flow formation processes in the Derekoyka River basin for the period 1967-1988 and 2016-2018 was carried out. Daily flow hydrographs and the distribution of water balance elements were obtained. The results were verified using observed data and evaluated as satisfactory. 
3. The hazardous flood, which was observed on September 6, 2018 in the resort town of Yalta, was simulated. Maximum simulated daily discharge amounted to 14.9 $\mathrm{m}^{3} / \mathrm{s}$. This value exceeded the previous maximum observed in 1962 .

Overall the results confirm the possibility to apply the hydrological model Hydrograph to assess the water balance and hydrological characteristics in the mountainous part of the Crimean Peninsula. Provided by proper precipitation data the model can be used for shortterm forecasts of hazardous floods in the region.

\section{Reference}

1. Book of the Crimea Peninsula records. URL:

http://www.planetakrim.com/catalog/06/index.html (Accessed: 03.03.2020)

2. Delovoy Peterburg Russian Newspaper URL: https://www.dp.ru/a/2018/09/07/V_JAlte potop_Moshhnij_po (Accessed: 20.02.2020)

3. $\mathrm{H}$ A.V. Holopcev, O.V. Parubec, Aktualnye problemy gumanitarnyh i estestvennyh nauk (8-1), pp. 233-238 (2014)

4. Landscape map of the USSR in 1980. Responsible editor: I. S. Gudilin. Scale 1:2500000 (in $1 \mathrm{~cm} .25 \mathrm{~km}$.). Ministry of Geology of the USSR.

5. O.M. Makarieva, N.V. Nesterova, T.A. Vinogradova, I.N. Beldiman, A.D. Kolupaeva, Vestnik of Saint Petersburg University. Earth Sciences, 64, 1, pp. 24-43 (2019)

6. O.M. Makarieva, N.V. Nesterova, G.P. Yampolsky, E.Yu. Kudymova, A.A. Ostashov, A.D. Kolupaeva, Engineering Survey, XIII, No. 2, pp. 36-51 (2019 in Russian)

7. O.M. Makarieva, T.A. Vinogradova, N.V. Nesterova, A.Yu. Vinogradov, I.N. Beldiman, A.D. Kolupaeva, Georisk, XII (3), pp. 78-89 (2018)

8. J.E. Nash, J.V. Sutcliffe, J. Hydrol 10, No. 3, pp. 282-290 (1970)

9. National Oceanic and Atmospheric Administration U.S. Department of Commerce URL:https://www.noaa.gov (Accessed: 03.03.2020)

10. Official website GUP RK "Voda Kryma". URL: http://voda.crimea.ru (Accessed: 05.02.2020)

11. Official website HYDROMETCENTER OF RUSSIA About the weather - at first hand URL: https://meteoinfo.ru (Accessed: 20.02.2020)

12. V.A. Ovcharuk, O.M. Prokofiev, E.I. Todorova, Visnyk of V.N. Karazin Kharkiv National University, series "Geology. Geography. Ecology"; № 42 (1157), pp. 99-106 (2015)

13. O.V. Parubec, Uchenye zapiski Tavricheskogo natsional'nogo universiteta im. V.I. Vernadskogo. Seriya: Geography 22(61), pp. 88-96 (2009)

14. O. Semenova, L. Lebedeva, N. Volkova, I. Korenev, M. Forkel, J. Eberle, M. Urban, Hydrol Sci J. 60, Issue 7-8, 1225-1241 (2015)

15. O. Semenova, L. Lebedeva, Yu. Vinogradov, Hydrogeol J. 21(1): 107-119 (2013)

16. Yu.B. Vinogradov, O.M. Semenova, and T.A. Vinogradova, Hydrol Process, 25: 10551073. (2011)

17. Yu.B. Vinogradov, T.A. Vinogradova, Matematicheskoe modelirovanie v gidrologii. Akademiya, Moskva, p. 544 (2010) 